\title{
Pelatihan Penggunaan Perangkat Lunak GeoGebra dalam Pembelajaran Matematika bagi Guru-guru SMA di Wilayah Insana dan Biboki
}

\author{
Elinora Naikteas Bano, Oktovianus R. Sikas, dan Fried Markus Allung Blegur \\ Prodi Matematika, Universitas Timor, Jl. KM 9 Sasi, Timor Tengah Utara, 85614 \\ E-mail: iranaikteas@gmail.com
}

\begin{abstract}
Abstrak - Capaian rata-rata nilai Ujian Nasional pelajaran Matematika Program Studi Ilmu Pengetahuan Alam tahun 2019 untuk wilayah Timor Tengah Utara adalah 31,15. Capaian ini merupakan yang terendah dibandingkan dengan nilai rata-rata mata ujian lain, baik pada tingkat kabupaten Timor Tengah Utara (TTU), provinsi Nusa Tenggara Timur (NTT), maupun Nasional. Kurangnya inovasi pembelajaran dan kreativitas guru seringkali menjadi kendala dalam pembelajaran matematika. Beberapa sekolah di wilayah Timor Tengah Utara dengan nilai rata-rata di bawah nilai rata-rata kabupaten, yaitu Biboki dan Insana, dipilih dan dilatih memanfaatkan perangkat lunak GeoGebra. Kegiatan pelatihan diawali dengan pengenalan GeoGebra dan dilanjutkan dengan pelatihan menyelesaikan berbagai persoalan matematika menggunakan GeoGebra. Kemudian dilanjutkan dengan kegiatan tindak lanjut dan pendistribusian video-video tutorial GeoGebra serta pendampingan dan bimbingan berkelanjutan. Setelah pelatihan, 52,38\% peserta telah menggunakan GeoGebra dalam pembelajaran.
\end{abstract}

Kata Kunci - geogebra, media pembelajaran, persoalan matematis

\begin{abstract}
Average National Examination score in 2019 for Mathematics Study Program territory North Central Timor (TTU) was 31.15. This achievment is the lowest average score of the other exams, both at the level TTU district, NTT province, and Nationals. Low learning innovation and teacher creativity often become problems in learning mathematics. Some schools in TTU have average scores below the district average that is Biboki dan Insana selected and trained to utilize software GeoGebra. This training begins with an introduction about GeoGebra and followed by training to solve various mathematical problems using GeoGebra. Then the proses follow-up with distribution of GeoGebra tutorial videos and ongoing mentoring and guidance. After training, 52.38\% of partisipants ready to use GeoGebra in their lessons.
\end{abstract}

Keywords - geogebra, media education, mathematics problems

\section{PENDAHULUAN}

Metematika merupakan salah satu mata pelajaran yang dinilai mampu membentuk cara berpikir siswa menjadi logis, teliti, terstruktur, praktis, kritis, kreatif, dan terampil dalam memecahkan masalah yang menantang dalam berbagai bidang [1], [2]. Kemampuan ini sangat dibutuhkan untuk menghadapi era globalisasi yang semakin kompetitif dalam bidang ilmu pengetahuan dan teknologi.

Pemahaman konsep, kemampuan berhitung, dan ketelitian dalam menyelesaikan soal mutlak diperlukan dalam pembelajaran matematika. Di sisi lain, sering kali ditemui bahwa banyak siswa menilai matematika merupakan pelajaran yang sulit dan tidak menyenangkan. Hal ini menyebabkan siswa menjadi tidak bersemangat dalam mengikuti proses pembelajaran matematika, sehingga berdampak pada rendahnya hasil belajar matematika.
Berdasarkan data Pusat Penilaian Pendidikan (Puspendik) Kementerian Pendidikan Nasional rata-rata nasional nilai Ujian Nasional (UN) pelajaran matematika tingkat SMA Program Studi IPA tahun 2019 adalah 38,60. Khusus untuk wilayah Nusa Tenggara Timur (NTT), capaian ratarata nilai UN pelajaran matematika SMA Program Studi IPA tahun 2019 adalah 31,68. Capaian ratarata nilai UN pelajatan matematika Program Studi IPA tahun 2019 untuk wilayah Timor Tengah Utara (TTU) adalah 31,15. Nilai-nilai ini merupakan yang terendah dibandingkan dengan nilai rata-rata mata ujian lain, baik pada tingkat Kabupaten TTU, Provinsi NTT, maupun Nasional.

Khusus wilayah Kabupaten TTU, dari lima kategori materi matematika yang diuji dalam UN, yaitu Aljabar, Kalkulus, Geometri dan Trigonometri, serta Statistika, nilai daya serap kurang dari 55,00 untuk hampir seluruh indikator yang diuji, sedangkan penguasaan materi matematika yang diukur dari soal-soal yang disajikan UN 
memperlihatkan bahwa persentase siswa yang menjawab benar untuk setiap kategori materi yang diuji adalah kurang dari $40 \%$.

Tabel 1. Persentase siswa yang menjawab benar soal Ujian Nasional mata pelajaran matematika tahun 2019

\begin{tabular}{lllll}
\hline No. & Materi yang diuji & $\begin{array}{c}\text { Kab. } \\
\text { TTU }\end{array}$ & $\begin{array}{l}\text { Prov. } \\
\text { NTT }\end{array}$ & Nasional \\
\hline 1. & Aljabar & 38,71 & 38,73 & 45,50 \\
2. & Kalkulus & 25,71 & 26,82 & 34,99 \\
3. & $\begin{array}{l}\text { Geometri dan } \\
\text { Trigonometri }\end{array}$ & 28,03 & 29,00 & 34,59 \\
4. & Statistika & 27,65 & 28,06 & 35,02 \\
\hline
\end{tabular}

Kurangnya inovasi pembelajaran dan kreativitas guru sering menjadi kendala dalam pembelajaran matematika. Akibatnya, siswa masih sering mengalami kesulitan dalam memahami materi yang disajikan. Di tengah pesatnya perkembangan teknologi dan informasi saat ini, pemanfaatan media berbasis teknologi diperlukan untuk menunjang efektivitas pembelajaran. Salah satu media pembelajaran yang dapat dimanfaatkan adalah perangkat lunak (software) berbasis pendidikan.

Salah satu perangkat lunak matematika yang dapat dimanfaatkan guru matematika adalah GeoGebra [3], [4]. Perangkat lunak ini dirancang untuk mempermudah pemahaman materi grafik, geometri, dimensi tiga, fungsi, trigonometri, kalkulus (integral), statistik, dan lain-lain [4]. Objekobjek grafik, geometri dan dimensi tiga dapat dengan mudah digambarkan dengan visual yang menarik. Selain itu, objek-objek yang telah digambarkan dapat dengan mudah dimodifikasi secara dinamis sesuai dengan kebutuhan dengan maksud agar siswa lebih mudah memahami maksud dari persamaanpersamaan serta konsekuensi dari perubahanperubahan yang diterapkan terhadap persamaan mula-mula [5]. Demikian juga untuk fungsi, triginometri, integral, dan lain-lain dapat dengan mudah dimodifikasi dan dilihat konsekuensi perubahan yang diterapkan.

Memperhatikan pencapaian nilai UN mata pelajaran matematika tahun 2019 dan keunggulan aplikasi GeoGebra, maka guru-guru perlu dibekali dengan pemanfaatan perangkat lunak GeoGebra. Beberapa sekolah di wilayah TTU dengan nilai ratarata masih di bawah nilai rata-rata kabupaten dipilih dan dibekali pengetahuan tentang pemanfaatan perangkat lunak GeoGebra dalam meningkatkan kemampuan siswa dalam pembelajaran matematika.

\section{METODE}

Metode yang digunakan dalam kegiatan ini berupa presentasi dan diskusi dalam bentuk workshop mengenai perangkat lunak GeoGebra dan pemanfaatannya sebagai media pembelajaran matematika. Selain itu diberikan pula pre-test dan post-test untuk mengetahui kemampuan guru-guru sebelum dan setelah diberikan workshop.

Mitra dalam kegiatan ini adalah guru-guru mata pelajaran matematika dari 7 SMA di wilayah Insana dan Biboki dengan pencapaian nilai rata-rata UN mata pelajaran matematika Program Studi IPA tahun 2019 di bawah rata-rata nilai UN mata pelajaran matematika Program Studi IPA kabupaten TTU $(31,15)$. Berikut daftar peserta workshop:

Tabel 2. Distribusi peserta pelatihan menurut sekolah

\begin{tabular}{llcc}
\hline No. & Nama Sekolah & $\begin{array}{c}\text { Rata-rata } \\
\text { Nilai UN } \\
\text { Matematika }\end{array}$ & $\begin{array}{c}\text { Jumlah } \\
\text { Peserta } \\
\text { (orang) }\end{array}$ \\
\hline 1. & SMAN Insana & 27,82 & 3 \\
2. & SMAN Insana Barat & 29,74 & 3 \\
3. & SMAN Insana Tengah & 28,10 & 3 \\
4. & SMAN Fafinesu & 26,83 & 3 \\
5. & SMAN Oekolo & 26,50 & 3 \\
6. & SMAN Lurasik & 29,76 & 3 \\
7. & SMAN Manufui & 30,44 & 3 \\
\hline
\end{tabular}

\section{HASIL DAN PEMBAHASAN}

Pada tahap pertama, Tim Pengabdi melakukan beberapa wawancara dan diskusi dengan Kepala Sekolah dan guru-guru Matematika setiap sekolah, serta menyebarkan kuesioner kepada guruguru untuk mengetahui taraf penggunaan media pembelajaran matematika dan manfaatnya dalam melancarkan penyampaian materi oleh guru dan penyerapan materi oleh siswa. Berdasarkan hasil wawancara, diskusi, dan jawaban kuesioner, diperoleh informasi mengenai masalah-masalah yang dihadapi oleh guru-guru dalam pelaksanaan pembelajaran Matematika, yaitu sebagai berikut:

a. Guru-guru menggunakan media gambar konvensional dalam pembelajaran matematika sehingga pembelajaran tidak berjalan secara efisien. Hal ini disebabkan karena banyak waktu yang dipergunakan guru untuk menggambar di papan tulis.

b. Kemampuan membuat gambar konvensional yang tidak cukup baik (rapi, teliti, dan menarik) menyebabkan gambar yang dihasilkan tidak 
cukup menarik minat siswa untuk belajar sehingga siswa tidak dapat menyerap secara baik informasi yang disampaikan oleh guru tentang konsep-konsep matematika dari gambar.

c. Guru-guru belum pernah memanfaatkan teknologi komputasi untuk membuat media gambar dalam pembelajaran matematika disebabkan oleh kurangnya pemahaman guru tentang penggunaan teknologi dalam pembelajaran.

d. Beberapa guru pernah mendapat informasi tentang perangkat lunak GeoGebra, tetapi belum pernah mempelajari dan menggunakannya dalam pembelajaran karena tidak memiliki panduan/modul.

Untuk menyelesaikan permasalahan di atas, guruguru perlu dilatih dan dibimbing untuk melakukan inovasi dalam pembalajaran dengan memanfaatkan perkembangan.

Pada tahapan kedua, guru-guru diberikan modul pelatihan satu minggu sebelum pelatihan dilaksanakan. Materi awal pelatihan adalah pengenalan dasar tentang perangkat lunak GeoGebra. Selanjutnya guru-guru dilatih menggunakan GeoGebra untuk menyelesaikan beberapa topik materi pembelajaran matematika.

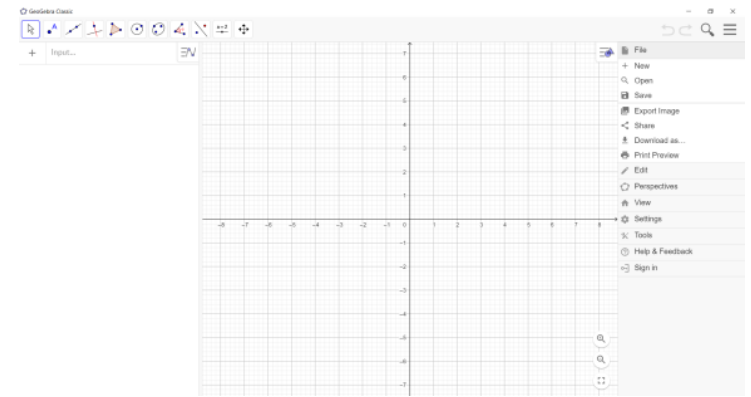

Gambar 1. Menu utama GeoGebra

Topik-topik yang dibahas didasarkan pada permintaan guru-guru menurut tingkat kesulitan menyampaikan materi dan kesulitan siswa dalam menyerap materi yang disampaikan guru. Berikut topik-topik yang dibahas dalam pelatihan:

a. Dimensi tiga,

b. Trigonometri,

c. Kurva, titik singgung, dan garis singgung,

d. Program linear,

e. Luas daerah antar kurva,

f. Integral, dan

g. Membuat tabel distribusi frekuensi, histogram, dan poligon frekuensi.

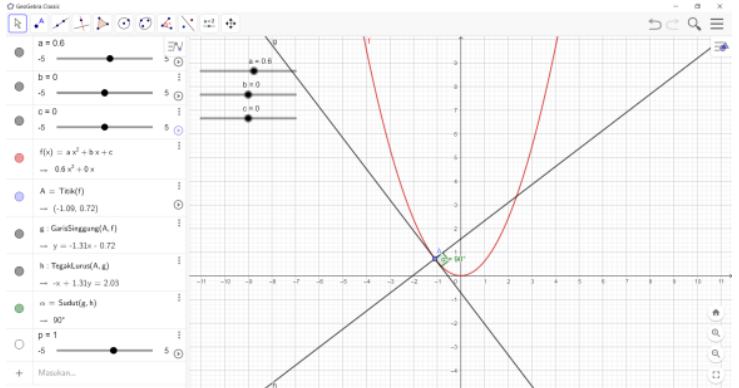

Gambar 2. Salah satu eksplorasi karakteristik kurva parabola, titik singgung, dan garis singgung menggunakan GeoGebra

Setelah pelaksanaan tahap kedua, dilakukan tahapan tindak lanjut yang terlaksana satu bulan setelah kegiatan tahap dua, dimana guru-guru diberi kesempatan untuk memperlihatkan penggunaan GeoGebra dalam menyelesaikan soal matematika kepada Tim Pengabdi. Selain itu, tindak lanjut juga dilakukan dengan membuka ruang diskusi dan mendistribusikan video-video tutorial penggunaan GeoGebra melalui fasilitias grup WhatsApp.

Tahapan terakhir adalah peserta mengisi kuesioner pasca pelatihan untuk mengetahui pengaruh pelatihan terhadap pemahaman guru tentang GeoGebra dan penggunaan GeoGebra dalam pembelajaran.

Tabel 3. Kondisi guru-guru sebelum dan sesudah pelaksanaan pelatihan

\begin{tabular}{ll}
\hline \multicolumn{1}{c}{ Sebelum Pelatihan } & \multicolumn{1}{c}{ Sesudah Pelatihan } \\
\hline $\begin{array}{l}\text { Guru-guru belum memiliki } \\
\text { pemahaman dasar tentang } \\
\text { GeoGebra }\end{array}$ & $\begin{array}{l}\text { Guru-guru telah memiliki } \\
\text { pemahaman dasar tentang } \\
\text { GeoGebra }\end{array}$ \\
$\begin{array}{l}\text { Guru-guru belum memiliki } \\
\text { panduan/modul GeoGebra } \\
\text { untuk dipelajari }\end{array}$ & $\begin{array}{l}\text { Guru-guru telah memiliki } \\
\text { panduan belajar GeoGebra } \\
\text { berupa modul dan video-video } \\
\text { tutorial penggunaan GeoGebra }\end{array}$ \\
$\begin{array}{l}\text { Guru-guru belum pernah } \\
\text { memanfaatkan teknologi } \\
\text { komputasi berupa perangkat } \\
\text { lunak sebagai media } \\
\text { pembelajaran di kelas }\end{array}$ & $\begin{array}{l}\text { Sebanyak 52,38\% guru-guru } \\
\text { yang mengikuti pelatihan telah } \\
\text { menggunakan GeoGebra } \\
\text { sebagai media pembelajaran di } \\
\text { kelas }\end{array}$ \\
\hline
\end{tabular}

Evaluasi pelatihan dilakukan secara bersamasama oleh Tim Pengabdi dan guru-guru dan menyepakati bahwa fasilitas grup WhatsApp yang telah dipakai selama pelatihan akan tetap digunakan sebagai sarana diskusi berkaitan dengan penggunaan GeoGebra meskipun kegiatan pengabdian telah selesai dilaksanakan. 


\section{KESIMPULAN}

Pelatihan penggunaan GeoGebra dalam pembelajaran matematika di SMA telah mendorong guru-guru untuk memanfaatkannya dalam pembelajaran matematika di kelas. Dari hasil kuesioner pasca pelatihan diperoleh informasi bahwa kemudahan penggunaan, visualisasi yang menarik, dan berbagai fitur dalam GeoGebra sangat membantu guru-guru dalam melaksanakan pembelajaran secara efektif dan efisien.

\section{UCAPAN TERIMA KASIH}

Penulis mengucapkan terima kasih kepada Lembaga Penelitian dan Pengabdian pada Masyarakat (LPPM) Universitas Timor yang telah mendanai pelaksanaan pelatihan penggunaan GeoGebra bagi guru-guru SMA di wilayah Biboki dan Insana. Penulis juga mengucapkan terima kasih kepada Kepala Sekolah dan guru-guru SMAN 1 Insana, SMAN Insana Tengah, SMAN Insana Barat, SMAN Fafinesu, SMAN Oekolo, SMAN Lurasik, dan SMAN Manufui yang bersedia menjadi mitra dalam kegiatan Pengabdian kepada Masyarakat ini.

\section{DAFTAR PUSTAKA}

[1] Asngari, D. R. 2015, Penggunaan Geogebra dalam Pembelajaran Geometri, Fakultas Keguruan dan Ilmu Pendidikan, Universitas Lampung. Seminar Matematika dan Pendidikan Matematika UNY, hlm. 299-302.

[2] Faradisa, M., Sulistio, M. Z., Ayu, Y., A. 2018. Penggunaan Aplikasi Geogebra pada Pembelajaran Matematika Materi Poligon dan Sudut Sebagai Sarana Meningkatkan Kemampuan Siswa. Jurnal Equation, vol. 01, no. 02 , hlm. 166-172

[3] Mahmudi, A. 2010. Membelajarkan Geometri dengan Program Geogebra. Yogyakarta: Seminar FPMIPA UNY, hlm. 1-12

[4] Siswanto, R. 2014. Peningkatan Kemampuan Penalaran dan Koneksi Matematis melalui Penerapan Model Pembelajaran Kooperatif Tipe Stad Berbantuan Software Geogebra (Studi Eksperimen di SMAN 1 Cikulur Kabupaten Lebak Propinsi Banten). Jurnal Pendidikan dan Keguruan, vol. 01, no. 01.

[5] Kustiawati, D. 2017. Pembelajaran Geometri Berbantuan Software Geogebra Terhadap Kemampuan Komunikasi Matematik Siswa. Jurnal Ilmiah Pendidikan Matematika, vol. 01, no. 02 , hlm. $113-120$ 